\title{
Cultural heritage in Korea - from a Japanese perspective
}

\author{
Toshio Asakura \\ National Museum of Ethnology
}

\section{Introduction}

The Korean television drama Dae Jang-geum has been popular not only in Korea but also throughout East Asia, including in Japan, Taiwan and China. It is based on the true story of Jang-geum, the reputedly first woman to hold the position of royal physician in the 16th-century during the Joseon Dynasty (1392-1897). What is interesting about the drama from a perspective of cultural heritage is that it serves to highlight traditional Korean culture, especially Korean court cuisine and medicine.

How to cite this book chapter:

Asakura, T 2016 Cultural heritage in Korea - from a Japanese perspective. In: Matsuda, A and Mengoni, L E (eds.) Reconsidering Cultural Heritage in East Asia, Pp. 103-119. London: Ubiquity Press. DOI: http://dx.doi. org/10.5334/baz.f. License: CC-BY 4.0 
I was in charge of supervising the Japanese-language version of this show, and one of the most challenging, yet interesting, aspects of my task was to work out how to translate Korean culture to a Japanese audience. ${ }^{1}$ By referring to this drama, which was part of the so-called 'Korean wave' (hanryû), I will investigate the circumstances surrounding three aspects of cultural heritage in Korea: culinary culture; Living National Treasures (i.e. holders of Important Intangible Cultural Properties); and cultural landscapes. Japan and Korea are said to share broadly similar cultural heritage, including amongst other things the influence of Chinese culture, as exemplified by the spoken language and script, and the influence of Confucianism. However, through comparison with Japan I will attempt to reveal some of the more distinct characteristics of cultural heritage in Korea, and also make a few suggestions pertinent to the discussion of cultural heritage in the East Asian context.

\section{Culinary culture}

Jang-geum, the protagonist in Dae Jang-geum, was based on a historical figure whose name appears in the Joseon Wangjo Sillok, the annual records of the Joseon Dynasty kept from 1413 until 1865. In the first half of the drama series, she appears as a lady of the court, responsible for preparing royal court cuisine. This is, however, a fictitious representation of her because the historical Jang-geum was a royal physician and did not perform such tasks. The reason behind this historically inaccurate rendering in the drama can be attributed to the concept in Korean culture known as yaksikdongwon, which claims that health is maintained by a combination of food and medical treatment.

While the popularity of the drama Dae Jang-geum can be explained by several factors, one of the most important factors is 
undoubtedly the growing interest in food in Korean society. ${ }^{2}$ The restaurant industry is currently developing fast in Korea, which is in part thanks to the contribution of many different foreign cuisines but is also due to the recent re-appreciation of the traditional Korean foods as being beneficial to health, the best example of which is 'court cuisine. ${ }^{3}$ Court cuisine offers something different from full-course traditional meals called hanjeongsik, which have long been available at many Korean restaurants. Court cuisine is, in fact, a brand developed by Hwang Hye-seong (1920-2006), who is designated as a holder of Important Intangible Cultural Properties, informally known as a Living National Treasure, in recognition of her skill in Korean royal court cuisine (Moon 2009). When Hwang Hye-seong began teaching Korean cuisine at Sookmyung Women's University in 1942, she was encouraged by the director of the University, Oda Shôgo, to study court cuisine, which at the time was on the verge of disappearing (Hwang \& Ishige 1988). She subsequently learned court cuisine from the last sanggun (court lady) in charge of cooking for the royal family, compiled its recipes, expounded it in a scholarly manner, developed it in a way suitable to contemporary life, and made it known to the world (An 2007). She founded the restaurant Jihwaja, located across from Unhyeon Palace in Seoul, which serves to bring court cuisine of the Joseon Dynasty to everyday people. In keeping with this strongly heritage-based approach to cuisine, the homepage of Jihwaja's website is entitled The Culinary Culture of the House of Hwang Hye-seong, and includes sections entitled 'The "Korean Royal Court Cuisine" of the 38th National Important Intangible Cultural Property', and 'People at the House of Hwang Hye-seong'.

This reconsideration of traditional cuisine has been linked with a national movement promoting the globalization of Korean food, ${ }^{4}$ one of the most prominent examples of which is 
the 'Japan-Korea Kimchi War'. Kimchi is perhaps the most wellrecognized Korean food around the globe, but in the mid-1990s it emerged that Korean kimchi was losing out to Japanese produced kimchi (or kimuchi, which is the Japanese pronunciation) in world markets. Following this news, in 1996 at a meeting of the International Food Standards Agency (CODEX), the Korean Ministry for Food, Agriculture, Forestry and Fisheries claimed that kimchi is a food that is naturally fermented, and therefore flavour-enhanced Japanese kimchi prepared with additives is not real kimchi. This controversy was widely publicized by the Japanese media in the summer of 1999 as the 'Japan-Korea Kimchi War'. This development appears to have been the first step in Korea's efforts to reaffirm kimchi's status in the World as a traditional and culturally Korean food (Asakura 2009).

As a way of improving Korea's national brand value through culture, President Lee Myung-bak decided to promote Korean food both domestically and abroad, and established the Korean Food Globalization Promotion Committee in 2009 and enacted a law to promote the restaurant industry in 2011. President Lee's wife, Kim Yoon-ok, became the honorary president of the Korean Food Globalization Promotion Committee and aimed to establish Korean food as one of the top five cuisines in the World, with particular emphasis on promoting bibimbap, a traditional rice dish with cooked vegetables. ${ }^{5}$ President Lee also sought personally to further the export of makkeolli, a traditional Korean liquor. In this way, Korea engaged in a worldwide strategy to spread Korean food as culture.

Let us now consider the contrasting circumstances in Japan with regards to the globalization of food. Japanese food has already been well known in various places in the World for some time, and increasing numbers of restaurants have been opening outside 
of Japan claiming to offer 'Japanese food', which however generally fails to resemble authentic Japanese cuisine. ${ }^{6}$ In response to this situation, in 2006 the Japanese Ministry of Agriculture, Forestry and Fisheries attempted to formulate a system of evaluating the authenticity of menus that claim to offer Japanese food. ${ }^{7}$ This move, however, received opposition both inside and outside of Japan. The Ministry subsequently decided to give up on the idea of establishing a governmental system for authenticating Japanese food and leave the matter to be dealt with by the private sector. Admitting the difficulty of providing a definition of 'Japanese food', the Ministry acknowledged that 'ingredients and methods of preparation should be determined by the practice in each country, and private evaluating organizations should be organized by food researchers in the actual locations' (Shimbun 2007).

In Japan, dietary culture has tended to be transmitted under private leadership. A notable example of this is the annual Kyoto Food Exhibition, which began in 1876 by owners of famous restaurants and still continues today. Another example can be found in the way in which new forms of dietary culture, such as gifting chocolate for Valentine's Day and eating rolled sushi during the Setsubun Festival held on February 3rd, have been generated and promoted by private business initiatives. This type of private leadership in Japanese food culture presents a strong contrast to Korea's recent tendency towards top-down governmental leadership.

The question that I would like to raise at this point is: to what extent can and should food be considered as part of cultural heritage? Although food may be part of material culture, it is perishable, and once consumed by people, it turns into human waste. In other words, unlike other types of material culture, food is difficult to maintain because it cannot be preserved in its original 
form and changes according to location and period. Food can, nevertheless, be described and preserved in written documents, and techniques of preparation can be handed down. Chinese and Japanese dietary culture has already spread worldwide, and Korea is fighting for a place in this development. In view of this, it would be reasonable to consider whether more attention should be given to food as cultural heritage in the East Asian context.

\section{Living National Treasures (holders of Important Intangible Cultural Properties)}

During the production of the drama Dae Jang-geum, the person responsible for providing dietary research was Han Bok-ryeo (1947-present), the eldest daughter of Hwang Hye-seong, discussed previously. In 2007, a year after Hwang Hye-seong passed away, Han Bok-ryeo became the third Living National Treasure in the field of royal court cuisine. The first person to be given this title in 1971 was Hwang Hye-seong's teacher, Han Hee-sun (1889-1972), who was also the model for Jang-geum's teacher in the television drama. At the age of twelve, Han Hee-sun started working in a position in the court's outer kitchen, but after ten years rose to the position of sanggun (court lady) of the inner kitchen and became responsible for preparing the royal meals for Emperor Gojong, Crown Prince Sunjong, and Lady Yoon. She lived at court until 1950, when Lady Yoon fled to Busan at the outbreak of the Korean War. Thereafter, Han Hee-sun taught court cuisine twice a week at Sookmyung Women's University (Ye 1976).

In 1962, the Korean Cultural Properties Protection Act was enacted to provide legal protection to four categories of cultural properties: tangible cultural properties; intangible cultural 
properties; monuments; and folk resources. ${ }^{8}$ According to the law, both the national and local governments can designate cultural properties to be protected, and the intangible cultural properties that are given a national designation are called 'Important Intangible Cultural Properties'.

As of December 2009, there were 114 nationally designated Important Intangible Cultural Properties, and its breakdown was as follows: in the field of performance arts, there were 17 for music, 7 for dance, 14 for theatre, 24 for ceremonies and types of popular entertainment, and 1 for martial arts; in the field of technical arts, there were 49 for crafts, and 2 for cuisine. The number of individuals designated as holders of these Important Intangible Cultural Properties was 184. On the local governmental level, on the other hand, there were 388 designated intangible cultural properties, and 470 individuals were designated as their holders (Chǒng 2009).

Korea has been active in not only protecting but also promoting its intangible cultural properties. For instance, the National Research Institute of Cultural Heritage, which is affiliated with the Cultural Heritage Administration of Korea (Chŏng 2009), has produced a series of books and videos to introduce the Important Intangible Cultural Properties in Korean and English. Additionally, the Bucheon World Intangible Cultural Heritage Expo, hosted by Bucheon City and supported by the Ministry of Culture, Sports and Tourism, was held in 2008 to 2010 to present intangible cultural properties from Korea and around the World.

In Korea, as in Japan, individuals designated as holders of Important Intangible Cultural Properties are popularly called 'Living National Treasures' or 'Living Cultural Properties', and they have a clearly recognised role in popular consciousness. Japan's Living National Treasures are selected for skills in the performance arts 
of court dance (gagaku), noh theatre, puppet theatre (bunraku), kabuki, traditional Ryûkyû narrative dance (kumi-odori), music, Japanese dance (buyô), engei and theatre; as well as for skills in the technical arts of ceramics, dyeing and weaving, Japanese stencil-making (Ise-katagami), lacquer, metalwork, sword making, doll making, woodwork, and paper making. Korea has more categories of Important Intangible Cultural Properties than Japan, extending even to cuisine and martial arts, and the number of their holders - namely Living National Treasures - is also greater (184 as of December 2009 as stated earlier). Recently, however, the increased numbers of Living National Treasures has generated a challenge to the transmission of the recognised skills for future generations in Korea (Koreana 1997: 13). This issue is in part related to the fact that, unlike Japan where generational succession to a family trade is fairly common and has a long history, in Korea the generational succession of traditional practitioners does not tend to be very strong. Consequently, the government needs to support traditional practitioners more actively in Korea than in Japan.

Since the end of the Korean War in 1953, there have been ongoing efforts in Korea to re-evaluate traditional practices and beliefs that were ignored and denigrated under the shadow of modernization. Many traditional folk practices and rural performances have consequently been uncovered, preserved, and designated as intangible cultural properties; even shamans and their rituals which were dismissed as superstitious until recently have now been protected with national and local designations. In this sense, the protection of intangible cultural properties in Korea has been more wide-ranging than in Japan.

At this point it is worth remembering that very few countries around the World have a system of designating and protecting 
intangible cultural properties. In view of this, it seems important to examine why the protection and promotion of intangible cultural properties has become a national policy in Japan and Korea in relation to the global discourse of cultural heritage.

\section{Cultural landscapes}

Han Bok-ryeo is currently the director of the Institute of Korean Royal Cuisine that is located in the area of Bukchon in Seoul, and she also runs a restaurant named Gungyeon which she opened in 2003 in Bukchon. Bukchon literally means 'Northern Village', and it was so named because of its location to the north of Jongno, which was historically the centre of Hanyang (the name for Seoul during the Joseon Period) and the River Cheonggyecheon. Bukchon is often dubbed the 'Korean Village' because a group of hanok, traditional Korean dwellings, still survive there. Historically, Bukchon stands between the Gyeongbokgung Palace and the Changdeokgung Palace, and used to be a place of residence for members of the royal family and powerful noble families known as yangban.

During the 1970s, the Korean government undertook many development works in the Gangnam District, a different area in Seoul, and this resulted in a few of the country's oldest schools in Bukchon being transferred to Gangnam. The area in Bukchon that used to be occupied by these schools now came to be occupied by newly built big modern buildings, the most famous of which are the headquarters of the Hyundai group and the Constitutional Court of Korea. This triggered a movement for preserving the traditional landscape characterised by the hanok and promoting traditional cultural activities in Bukchon. As a result, the area has been culturally revitalised and become a place of residence for 


\section{II2 Reconsidering Cultural Heritage in East Asia}

artists and business and political leaders, with its traditional craft workshops and museums marking it out as a tourist destination.

In contrast to Bukchon, the area of Pimatgol in Seoul has lost its traditional landscape almost entirely. Pimatgol has its origins in the Joseon dynasty, when it developed along a street that ran in parallel with the major avenue Jongno; the street of Pimatgol was built for common people trying to avoid the traffic of government and court officials riding on horseback on Jongno. The street was for a long time famous for its line of restaurants where people could satisfy their appetites and quench their thirst in their everyday life. However, in 2003, permission was granted to redevelop the area, and construction of skyscrapers began. Voices were then raised for the heritage protection of Pimatgol, and in 2004 guidelines were published in support of the historical preservation of the area. The guidelines, however, had little effect, and all the traces of Pimatgol except the street itself have disappeared. ${ }^{9}$

The loss of a characteristic cultural landscape has been observed not only in Pimatgol but also many other places across Korea. In 1993, the Korean art historian Hong-jun Yu (2000: 3) reflected on Korean heritage as a whole and made the following observation:

'The entire Korean peninsula is a museum...[it] is so small... The passage of history is carved into this small land, so wherever one travels here, one encounters examples of tangible and intangible cultural heritage. From glorious royal lands to villages hidden in deep mountains, these examples of cultural heritage have lost none of their vigour but are firmly alive'.

Despite this observation, like most parts of the World Korea has experienced the desire and the need for economic development and modernisation, often acting against preservation of traditional landscapes. In particular, under its military government 
(1961-1987) Korea saw a high degree of economic development, which came to be dubbed 'the Miracle of the Han River', and continued to accelerate even after the change to a democratic government.

The rapid and often abrupt changes in many cultural landscapes, both rural and urban, that have taken place in Korea over the last several decades were noted by the Japanese historian and cultural essayist Yomota Inuhiko, who visited Korea for the first time from 1979 to 1980, and then in 2000. On his second visit he wrote: 'It has completely changed. The entire Seoul port that I used to know has somehow become an object for nostalgia' (Yomota 2001: 2, 52). During this short period of time, the appearance of Seoul had been completely transformed. ${ }^{10}$ With this in mind, I would like to raise the issue of landscape conservation and restoration.

In Japan, along with the conservation of urban landscape (as practiced at Kanazawa and Uji), there has recently been much re-appreciation of the importance of landscapes closely associated with the daily lives and customs of local people, including those living near terraced rice fields and within mountain villages (satoyama). In 2005, the Japanese Law for the Protection of Cultural Properties was revised to adopt a new category 'cultural landscapes' with the aim of giving legal protection to the nationally designated 'Important Cultural Landscapes' (see Mouri's chapter in this book). Recently, Korea has also endeavoured to recognize the importance of urban landscapes through such projects as the restoration of the River Cheonggyecheon and the Gyeongbokgung Palace in Seoul. However, the conservation of rural landscapes that have evolved in association with the livelihood and customs of the local population are still in the course of development.

As globalization continues, the risk of losing historically developed cultural landscapes to monotonous and often sterile new 
sights increases. Asian cities have various faces - some are disordered, and some are aesthetically mediocre. Should such unimpressive faces be allowed to disappear for the sake of improving landscapes? If those faces are also to be considered examples of cultural heritage, then in what form should they be preserved?

\section{Conclusion}

In this chapter, I have compared Korea and Japan in connection with three topics: culinary culture, Living National Treasures, and cultural landscapes. To Japanese eyes, in contrast to Japan, cultural heritage in Korea has developed 'from the top', dynamically and rapidly. What might account for this difference? Both Korea and Japan have since ancient times been influenced by Chinese civilization, including the culture of Chinese characters and Confucianism. Geo-politically speaking, however, they are different in that Korea is a peninsula whereas Japan is an archipelago. Moreover, the Korean peninsula has a long history of dynastic rule; for example, during the Joseon dynasty, Confucianism was treated as orthodoxy and the literati ruling class governed the country for five hundred years - from the 14th-century onward. By contrast, in Japan from the 16th-century, although Confucianism served as the ideology of rulership, warriors held power and a social system based on Confucian principles did not emerge. Confucian principles underpinned the social system on the Korean peninsula, and they continue to inform society and daily life in Korea today, meaning that conditions there are somewhat different from those in Japan.

During the early modern period (ca. early 1500 s to late 1800 s), the Korean peninsula was ruled by a centralized government in the form of the long-established Joseon dynasty. This form 
of centralized government persisted well into modern times when Korea fell under military rule during the colonial period (1910-1945). By contrast, prior to the establishment of an 'enlightened state' during the modern period, Japan operated under the bakufu (military government) system of regionally divided power during the Edo period (1600-1868). Although a 'warrior-farmer-tradesman-merchant' class system was in place at this time in Japan, praise was awarded to anyone who succeeded in his particular field, regardless of class. On the other hand, society on the Korean peninsula was built around an agricultural economy in which anyone who made a living by special skills outside agriculture tended to be despised. For this reason, people with culinary skills have traditionally been respected in Japan and this has made way for eating and drinking establishments to develop into family businesses; whereas in Korea this was not traditionally the case so such establishments tend only to span one generation.

Japan and Korea also display differences in regard to interest in material culture:

'Based on the Confucian nature-as-principle teaching which served as the fundamental ideology of the literati ruling class during the Joseon dynasty, a human-centred world-view prevailed in which personal introspection was valued, and external material culture, technology, trade and consumption tended to be neglected. There was little discussion regarding the relationship between human beings and things that are not human beings' (Itô 2003: 13).

The difference appears in the single word 'thing'. The Japanese word for 'thing' (mono) can be used in many different ways, and no equivalent can be found for it in Korean. ${ }^{11}$ 
Following from these historical and cultural conditions, one economic policy has been promoted in Korea since the colonial period and the war, 'to pursue and overtake Japan'. On the other hand, a cultural policy has also been worked out to uncover and protect traditional culture. ${ }^{12}$ National strategy has been to create a revitalised traditional culture, to promote culture, and so to generate new forms of cultural heritage. In this respect it seems to me that the creation of new forms of cultural heritage is more likely to occur in Korea than in Japan.

\section{Notes}

${ }^{1} \mathrm{I}$ am an ethnologist, and became involved in supervising a historical drama because it was thought that I could provide something different from the information available through historical research; in particular explaining history from a contemporary perspective.

${ }^{2}$ One indication of the interest in food is the many gourmet cooking programs on Korean television. Also, the cartoon Sikgaek (The Gourmet) is popular in Korea and has been turned into a movie (like Japan's Oishinbo).

${ }^{3}$ Neither Japan, which has an emperor, nor England, which has a queen, has a royal 'court cuisine'. Royal court cuisine can exist in Korea perhaps, ironically, because the country no longer has a royal court.

4 Throughout 2009, the Korean newspaper Joong Ang Daily published articles about the plan for the 'globalisation of Korean food'.

5 The globalisation of bibimbap is discussed in Kuroda Katsuhiro's critical essay 'What is the Burden of Bibimbap?' published in Sankei Shimbun (26 December 2009). Koreans objected to the essay, and Kuroda responded with another essay in Sankei Shimbun entitled, 'Bibimbap Terrorism?' (9 January 2010).

${ }^{6}$ In reference to the development of Japanese restaurants abroad, the Asahi Shimbun published an article stating that 
worldwide Japanese cuisine has gone 'beyond a boom, moving toward a global standard' (15 January 2008).

${ }^{7}$ Italy and Thailand have a system of nationally authorised restaurants. In France, private organisations give seals of recommendation for French cooking.

${ }^{8}$ Until 1962, Korea followed the Japanese model of protecting cultural properties. However, with the enactment of the Korean Law for the Protection of Cultural Properties in 1962, the system was revised and developed along independent lines (Ôhashi 2004).

9 A Pimatgol bar with a 65 year history was reportedly moved to the Seoul History Museum (Joong Ang Daily, 5 February 2010).

${ }^{10}$ The Olympics and the World Exposition set off this rapid economic expansion. Japan held the Olympics in 1964 and the World Expo at Osaka in 1970. The Olympics were held in Korea in 1988, and the Taejon Expo took place in 1993.

${ }^{11}$ In a Japanese-Korean dictionary, the word mono brings up words meaning thing, object, and stuff, but these do not convey the other meanings of mono that appear under Japanese dictionary definitions of the word, including matter, word, reason, and spirit. In Japanese there is also a difference between mono when written in hiragana and when written in Chinese characters. This has been discussed as follows. Abito Itô has raised the issue of the difference between mono when written in hiragana and when written in Chinese characters (see Asakura 2003: 3-4).

12 'Tradition' refers to history and things from the past, but it is 'a past that has been selected' or 'a history with significance' for contemporary society. For a further discussion of traditional culture in Korean society, see my essay 'Gendai Kankoku shakai ni okeru "dentô bunka" no kenkyû no gendai to tenbô' (Asakura 1992).

\section{References}

An, H 2007 Culinary Researcher Hwang Hye-Seong. Seoul: Namusup. 
Asakura, T 1992 Gendai Kankoku Shakai Ni Okeru "Dentô Bunka” No Kenkyû No Genjô To Tenbô (The Current Status and Prospect of the Research on "Traditional Cultures" in Modern Korean Society). Kokuritsu Minzokugaku Hakubutsukan Kenkyûu Hôkoku (Bulletin of the National Museum of Ethnology), 17 (4): 809-851.

Asakura, T 2003 Hajime Ni (Introduction). In: Asakura, T (ed.) Mono Kara Mita Chôsen Minzoku Bunka (Korean Ethnological Culture Seen from Objects). Tokyo: Shinkansha. pp. 3-5.

Asakura, T 2009 Ekkyôsuru kimchi (Kimchi That Crosses Borders). In: Shoji, H (ed.) Imin To Tomoni Kawaru Chîki to Kokka (The Locality and the Nation That Change with Immigrants). Kokuritsu Minzokugaku Hakubutsukan Chôsa Hôkoku (Senri Ethnological Reports), 83: 59-67.

Hwang, H and Ishige, N 1988 Kankoku No Shoku (Food in Korea). Tokyo: Heibonsha.

Itô, A 2003 Kankoku De "Mono O Tôshite-Miru" Koto (What One Sees through Objects in Korea). In: Asakura, T. (ed.) Mono Kara Mita Chôsen Minzoku Bunka (Korean Ethnological Culture Seen from Objects). Tokyo: Shinkansha. pp. 11-24. Koreana (ed.) 1997 Tokushû: Gendai Ni Ikizuku Kankoku No Bunka Isan (Cultural Heritage That Lives in Present Society in Korea), 10 (1).

Moon, O 2009 Dining Elegance and Authenticity: Archaeology of Royal Court Cuisine in Korea. Chinese and Northeast Asian Cuisines: Local, National, and Global Foodways Proceedings. In: The 11th Symposium on Chinese Dietary Culture / 2009 ICCS International Symposium, CAPAS, Academia Sinica, Seoul, Korea, 12-14 October 2009.

Munhwajae Chŏng (Cultural Properties Administration) 2009 Statistical Data on Intangible Cultural Properties. Seoul: Munhwajae Chŏng.

Ôhashi, T 2004 Kankoku Ni Okeru Bunkazai Hôgo Shisutemu No Seiritsu To Tenkai: Seikino Tadashi Chôsa (1902) Kara Kankoku Bunkazai Hôgohô Seitei (1962) Made (The Establishment and Development of the System for the Protection of 
Cultural Properties in Korea: from the 1902 Survey by Sekino Tadashi to the 1962 Enactment of the Law for the Protection of Cultural Properties). In: Sôgô Seisaku Ronsô (Shimane Journal of Policy Studies), 8: 173-245.

Ye, Y 1976 Kankoku No Ningen Kokuhô (Living Treasures in South Korea). Tokyo: Perikansha.

Yomiuri S 2007 Nihonshoku Restoran Ninshô: 'Tadashî Nihonshoku' No Kijun Môkezu (Authenticating Japanese Restaurants: Decided Not to Establish Standards for 'Correct Japanese Food'). 17th March 2007.

Yomota, I 2001 Souru No Fûkei: Kioku to Henbô (Landscapes in Seoul: Memory and Change). Tokyo: Iwanami Shoten.

Yu, H 2000 Watashi No Bunka Isan Tôsa Ki (Memoirs of My Visit to Cultural Heritage Sites). Tokyo: Hôsei University Press. 